\title{
DIE SKOPUS VAN DIE HEILIGE SKRIF
}

\section{Inleiding}

Eerder as om 'n samevatting van my proefskrif ${ }^{1}$ te gee, wil ek in die bestek van enkele paragrawe sommige van die vernaamste bevindings probeer aanstip. Die eintlike bydrae lê in hoofstuk 3: „Die Skopus van die Heilige Skrif". $\mathrm{Na}$ my wete is dit die eerste sistematiese ondersoek na 'n begrip wat in die huidige Skrifdiskussie 'n sentrale rol speel.

Veral die afgelope dekade is o.a. gekenmerk deur besondere aandag aan die skopus van die Skrif. Dit beteken nié dat dit 'n nuwe begrip in die Skrifleer is nie, maar wel dat dit besondere beklemtoning ontvang het, te meer omdat die leer oor die Heilige Skrif as sodanig in die sentrum van diskussie is. Waarskynlik deels vanweë die feit dat die gedagte van die skopus egter nie vroeër 'n selfstandige deel van die leer oor die Skrif gevorm het nie, is dit tans nog nie heeltemal duidelik wat onder hierdie begrip verstaan word en wat die funksie daarvan in die Skrifleer is of behoort te wees nie.

\section{Algemene oriëntering}

Die saak (en selfs die begrip) het diep wortels in dic kerklike tradisie. Die gedagte van 'n bepaalde gerigtheid, konsentrasie of sentrum is so oud soos die apostoliese prediking self, dus vanaf die tyd van die apostoliese vaders en apologete. ${ }^{2}$ Bekend is die uitspraak van kerkvader Augustinus dat die Heilige Gees ons in die Skrif nie dinge wil leer ,nulla saluti profutura". ${ }^{3}$ Hierdie uitspraak van Augustinus is later ook instemmend deur Thomas van Aquino aangehaal.

By die lees van Luther se werke kom mens op allerlei spanninge in sy Skrifbeskouing af wat nie „opgelos" kan word nie. So beweer hy enersyds dat die hele Bybel voortdurend voor oë gehou moet word om die goeie wil van God te begryp. ${ }^{4}$ Andersyds beklemtoon hy dat slegs dié Bybelboeke aanneemlik is "was Christum treibet". diepste gaan dit tog vir Luther om die boodskap van die Heilige Skrif, om Jesus Christus, anders sou die Skrif niks méér wees nie as ,een metaphysische document".

Calvyn verskil van Luther daarin dat die konsentrasie op die Christologiese sentrum met die aksentuering van die verlossing by hom ontbreek. Die tese „sola Scriptura" is by Calvyn veel meer die grens van alle geloofskennis. Sy beskouings is wél Christosentries, maar in en deur Jesus Christus kry die mens ook kennis van God se skeppingsheerlikheid. Die beklemtoning hiervan deur Calvyn is van buitengewone belang vir 'n suiwere verstaan en insig in die skopus van die Heilige Skrif. Die ware kennis van God, aldus Calvyn, is gerig op die verering van sy Naam. Die soteriologiese konsentrasie by Luther is vir Calvyn nie doel in sigself nie, maar veel eerder die herstel van die gemeenskap met God. Die mens vind sy uiteindelike bestemming in die verheerliking van God in Christus Jesus: soli Deo Gloria. ${ }^{7}$ Calvyn maak verder onderskeid tussen die noodsaaklike en die nie-noodsaaklike leerstukke waar hy o.a. praat van "those 
things of which one may be ignorant, without violating the substance of religion and forfeiting salvation". ${ }^{8}$

Die Heilige Skrif het, volgens $H$. Bavinck, 'n bepaalde sentrum en met die inhoud van die Skrif hang "ook ten nauwste de bedoeling en de bestemming der Schrift samen". ${ }^{\circ}$ Hy sê die Skrif „dient om ons wijs te maken tot zaligheid"..0 In die Skrif gaan dit vir Bavinck om „de zaligmakende kennisse Gods. Daarvoor biedt de Schrift ons alle gegevens".

G. C. Berkouwer sluit in sy Skrifleer direk en doelbewus by Bavinck aan. So duidelik en sterk verdiskonteer Berkouwer die doel en gerigtheid van die Heilige Skrif, dat mens sonder vrees vir tcëspraak kan sê sy hele Skrifbeskouing daarmee staan of val. Herhaaldelik hou hy hom uitvoerig met die problematiek rondom die skopus van die Heilige Skrif besig. ${ }^{11}$ Berkouwer het genoegsaam bewys gelewer dat die beklemtoning en verdiskontering van die skopusgedagte legitiem is omdat die Skrif sélf dié genuanseerdheirl vertoon.

Ook in ' $n$ ander reformatoriese tradisie van ons eeu speel die skopusgedagte 'n belangrike rol, o.a. by Karl Barth ${ }^{12}$ en Otto Weber. ${ }^{13}$ Anders as Weber en Berkouwer, staan Barth enigsins vór die tydperk waarin die skopus so sterk onder die soeklig gekom het. Hierdie begrip speel dan ook geen besondere rol by Barth nie - die saak egter wel. Weber noem Jesus Christus „die Mitte der ganzen Schrift". 14

Ook in Vaticanum II het 'n bepaalde heilskonsentrasie sterk na vore gekom, 0.a. in "Dei Verbum" ${ }^{15}$ waaruit duidelik word hoeseer Vaticanum II 'n wins op Trente en Vaticanum I is. Van die Skrif sê „Dei Verbum” dat dit seker, getrou en sonder foute die waarheid leer wat God ter wille van ons heil wou laat opteken, en elders is sprake van die diepte van die waarheid wat in die openbaring oor God, en oor die mens se heil ontsluit is. ${ }^{18}$

Ons kan dus op grond van hierdie beknopte oorsig met redelike sekerheid aanneem dat hierdie insig van 'n bepaalde tendens, konsentrasie, bestemming of skopus van die Heilige Skrif in breë reformatoriese én Rooms-Katolieke kringe aanvaar word. Maar sodra mens hierdie skopus nader wil omskryf, duik dringende probleme op, waarvan ons kortliks enkeles sal aandui.

\section{Enkele probleme}

Die hele problematiek van die skopus van die Heilige Skrif lê rondom die dogmatiese vulling van dié begrip. Allereers die vraag na die omvang of breedte van die skopus, en implisiet daarin gegee die vraag na die gevaar van 'n dualisme.

Uit ons verwysinge na Augustinus, Thomas, Luther en Bavinck is dit duidelik dat die Naam Jesus Christus en die begrip heil van die vroegste tye af 'n oorheersende rol in die omskrywing van die skopus van die Heilige Skrif gespeel het. Die vraag is egter of hiermee die skopus nie te eng gestel is nie - en daarmee saam kom altyd die vraag na vore of dit nie 'n dualtsme impliseer nie. In die twintigste eeu staan in die reformatoriese teologie name soos Bavinck, 
Barth, Weber en Berkouwer baie naby aan mekaar in die omskrywing van die skopus. Bavinck praat van die deur-en-deur religieusetiese bestemming van die Heilige Skrif en sê dat dit teologies gelees moet word. Hieronder verstaan hy die saligmakende kennis van God, of die Woord van God tot saligheid. Berkouwer sluit so direk, bewustelik en kritiekloos by Bavinck aan dat hy oor die inhoud van die skopus nie bo Bavinck uitgaan nie. Maar juis dit stel ons voor die vraag of die skopus op dié wyse breed genoeg gevul is. Om die probleem helder te stel, word kortliks aandag gegee aan die standpunt van A. A. van Ruler.

Van Ruler sien die boodskap van die Ou Testament (én die Nuwe Testamenti7) as die boodskap van die koninkryk van God. Die skopus van die Heilige Skrif as geheel is dus die koninkryk en nié net Jesus Christus nie. Hy sien die heil in Christus, dit wil sê geloof, kerk en sending as middele wat lei na die uiteindelike doel van alles. In dié toekomsverwagting - die eschaton (nuwe aarde) kom die breedheid en die aardsgerigtheid na vore. ${ }^{18}$ Wat is volgens Van Ruler die hart van die Bybel? "In die eerste plaats het inzicht in de meerwaarde, zelfs in de zelfstandigheid van de betekenis van het Oude Testament. Dat inzicht kan ons bevrijden van de kramp van de christologische concentratie. In de tweede plaats het inzicht, dat ook de geschapen werkelijkheid zonder meer Woord van God te noemen is. Dit inzicht kan ons bevrijden van wat de Duitser noemt de soteriologische Engführung". ${ }^{10}$

Uit dié beknopte bespreking van die standpunt van Van Ruler blyk dat die skopusbegrip by hom veel breër gevul is as by Bavinck, Barth, Weber en Berkouwer. Die aspek aangedui deur die teokrasie, die sosiale ideaal en die nuwe aarde staan onweerspreeklik by Van Ruler in die sentrum van die Heilige Skrif. Natuurlik moet onmiddellik bygevoeg word dat die ander teoloë (Bavinck ens.) die teokratiese gedagte nie eksplisiet uitsluit nie, maar die vraag is of dit nie eksplisiet ook ingesluit moet word in die skopus nie. Ten opsigte van die enger benadering (Bavinck ens.) moet egter opgemerk word dat hulle siening op die skopus van die Skrif makliker tot 'n dualisme aanleiding kan gee as dié van Van Ruler. En juis omdat die gevaar van 'n dualistiese Skrifbeskouing een van die skerpste punte van kritiek teen die skopusgedagte bly, sal hierop nader ingegaan moet word.

Berkouwer het herhaaldelik op hierdie gevaar gewys en aangetoon dat daar inderdaad so 'n gevaar bestaan maar dat dit op sigself geen legitieme kritiek teen die skopusgedagte is nie..20 Die skopus kán tot 'n dualisme lei maar dit hoef nie noodwendig nie, juis omdat die Skrif sélf so onmiskenbaar in 'n bepaalde rigting wys en ' $n$ bepaalde konsentrasie vertoon. Trouens Berkouwer het aangetoon dat 'n nivellering van die Skrif tot 'n boek met soveel gelykstaande, selfstandige waarhede juis die Skrifgesag ondermyn én verder dat die Skrif slegs dán suiwer verstaan kan word wanneer voluit erns gemaak word met sy skopus.21

Juis in dié lig is dit dan gebiedend noodsaaklik om nader in te gaan op die inhoud van die skopus van die Heilige Skrif. En dan sal dit dadelik blyk dat bv. Bavinck se standpunt wel in die rigting 
van 'n dualisme geïnterpreteer sou kon word - al het hy dit natuurlik geensins so bedoel nie. Soos reeds aangetoon, sê Bavinck dat die bestemming van die Skrif gerig is op die saligmakende kennis van God, en ongetwyfeld is dit veel enger gestel as Van Ruler.

\section{Die skopus prinsipieel besien}

\subsection{Die Ou Testament}

\subsubsection{Ken die Ou Testament 'n „sentrum"?}

'n Studie van die gangbare teologieë van die $\mathrm{Ou}$ Testament laat blyk dat dit moeilik is om één sentrale tema in die Ou Testament aan te dui waarop die geheel van die 39 boeke van die Ou Testament gerig is. H. L. Ellison sê dit kom voor asof die Ou Testament géén sentrale boodskap het nie en dat die inhoud daarvan maar verwarrend is om te verstaan. ${ }^{22}$ Ook P. A. H. de Boer is van oortuiging dat dit geen gemaklike taak is om dié boodskap van die Ou Testament te formuleer nie. ${ }^{23} \mathrm{~A}$. S. van der Woude meen dat die inhoud van die Ou Testament so ryk en so gevarieerd is, "dat het niet mogelijk is die in één eenvoudige formule samen te vatten". ${ }^{24}$

Reeds sedert die begin van die vorige eeu het wetenskaplikes dikwels probeer om ' $n$ middelpunt van die Ou Testament te vind en dié soektog gaan vandag nog onverpoosd voort. G. Fohrer stel dit soos volg: „The crucial problem today regarding the theology of the Old Testament is: Is there a centre from which it can proceed and round which everything can be grouped?" ${ }^{25}$ Dié vraag na die skopus van die Ou Testament is van die allergrootste belang vir die verstaan en verklaring van die Ou Testament. ${ }^{28}$ Vroeër is onbevange oor die „wese" en ,die gronustrukture" van die Ou Testament gespreek, maar in die jongste tyd is die geleerdes met hul vraag na „die Mitte des A.T." veel meer beskeie. ${ }^{27}$ Koole stel sy siening onomwonde: „We moeten erkennen dat we geen antwoord op de vraag naar het centrum van het O.T. hebben". ${ }^{28} \mathrm{Hy}$ sê die kontraste lyk te groot om begripsmatig tot één hoofgedagte herlei te kan word. Koole wys daarop dat daar in die Ou Testament plek is vir kultiese vroomheid én vir die verwerping daarvan. Naas die partikularisme van Esra staan die universalisme van Rut en Jona. Die kanon omvat sowel Ps. 73 as Hooglied.

Een van die moontlikhede wat oorweeg moet word, is die vraag of Jahwe nie die sentrum van die Ou Testament is nie. Fohrer beantwoord die vraag negatief, want ,the Old Testament does not place God in its centre in an isolated manner, but speaks of him with regard to his action in the lives and destinies of nations and men, in creation and nature. It does not speak of God's existence and nature as it is in itself and its complete fullness, but of God's nature and action in regard to man". ${ }^{2 \theta}$ Aanvanklik het Von Rad betoog dat die Ou Testament geen sentrum (Mitte) het nie, maar later het hy aanvaar dat Jahwe die sentrum van die Ou Testament is. ${ }^{30}$

' $n$ Ander moontlikheid is die verbond as sentrum van die Ou Testament, en onmiddellik word aandag gevra vir die teologie van W. Eichrodt. Hasel sê Eichrodt se teologie „represents one of the 
most impressive attempts to understand the Old Testament as a whole not only from a centre but from the unifying "covenant". ${ }^{31}$ Die belangrikheid van die verbond as motief kan nie ontken word nie. Die vraag is egter: „Is the covenant concept broad enough to include adequately within its grasp the totality of O.T. reality?" ${ }_{32}$ Hierdie vraag beantwoord Hasel negatief, en die probleem bly ,, whether or not any single concept should or can be employed for bringing about a 'structural unity of the O.T. message' when the O.T. message resists from within such systematization". ${ }^{33}$

Dit is duidelik dat, na die oortuiging van baie Ou-Testamentici, die $\mathrm{Ou}$ Testament nie één sentrum het nie, maar dat aan meer as een sentrum of konsentrasie gedink sal moet word. Koole erken dat in 'n bepaalde tyd van Israel se historiese bestaan bepaalde gedagtes sentraal kon gestaan het. ${ }^{34}$ Fohrer sien twee sentrale gedagtes: „The centre of a theology of the old Testament lies in two thoughts: namely the rule of God and the communion between God and man". ${ }^{36}$ Dit kom dus daarop neer dat hy die koninkryk van God (of Jahwe is Koning) en die verbond gesamentlik as die skopus van die $\mathrm{Ou}$ Testament sien. Ook R. Smend aanvaar twee temas: Jahwe, die God van Israel, Israel, die volk van Jahwe. ${ }^{36}$ Smend se standpunt kom eintlik daarop neer dat Jahwe, die God van Israel, die middelpunt van die Ou Testament is. In die Nuwe Testament word Jahwe deur die Naam Jesus Christus vervang, en vir Smend is alle teologie Christologie.

Enersyds blyk dit dus dat Ou-Testamentici konkludeer dat die Ou Testament nie slegs één sentrum ken nie, maar verskeie. Von Rad, Smend en E. Sellin sien Jahwe as dié konsentrasie. Andere soos Th. C. Vriezen, H. Wildberger, Eichrodt sien weer die verbond as sentrum. Nog ander weer beklemtoon die sentraliteit van die koninkryk van God. ${ }^{37}$

Andersyds het dit ook duidelik geword dat die Ou Testament wél sekere konsentrasies ken soos Jahwe, verbond, koninkryk, en die vraag is nou of daar nie 'n (direkte?) verband tussen hierdie konsentrasies is nie. Dit is bv. 'n vraag of 'n bepaalde dubbelheid (Fohrer: Koninkryk van God én verbond; Smend: Jahwe, die God van Israel, én Israel, die volk van Jahwe) nie twee kante van één saak is nie. Om hierdie vraag te beantwoord, word die volgende sentrale temas (of gedagtes) aan die orde gestel: Jahwe, verbond en koninkryk van God.

\subsubsection{Jahwe}

Th. C. Vriezen het op die Ou-Testamentiese Godsnaam ingegaan en sê daarvan 0.a.: "De eigenlijke israelitische Godsnaam is Jahwe". ${ }^{38}$ Die Naam Jahwe kom 6823 keer in die Ou Testament voor, dus meer dikwels as enige ander Godsnaam, en De Groot en Hulst wys daarop dat „Jahwe is in zeer bijzondere zin als een eigenaam te beschouwen; als de eigenlijke naam van God, die Israël vereerde". ${ }^{3 \theta}$ Dié Naam, wat so sentraal staan in die Ou Testament, word verkondig ter onderskeiding van die gode van die omliggende volke soos Kamos, Mardoek e.a. 
Van wanneer af is die Naam Jahwe bekend? Enersyds lyk dit asof dié Naam nie aan die aartsvaders bekend was nie (Ex. $3: 6$ ), maar andersyds stel Gen. 4: 26 dat Jahwe reeds in die dae van Enos aangeroep is. De Groot en Hulst skryf: „Het zou onjuist zijn, deze uiteenlopende gegevens in deze zin te interpreteren, dat weliswaar de naam Jahwe veel ouder was dan Mozes, maar dat de binding van de naam Jahwe uitsluitend aan Israël het werk van Mozes zou zijn geweest. Het is op verschillende plaatsen in Genesis immers juist de bedoeling duidelijk te maken, dat ook de voorvaderen van de latere Israëlieten geen andere God hebben gediend, al gebruikten ze andere benamingen". ${ }^{40}$ Ook Von Rad neem aan dat die Naam Jahwe nie vóor Moses bekend was nie: „Auch das traditionell gewordene Bild von der Heilsgeschichte, dem die Hexateuchquellen folgen, weiss darum, dass Jahwe seinen Erwählten nicht von Anfang an offenbar war, sondern dass sich die Offenbarung seines Namens erst in der Mosezeit ereignet hat". ${ }^{41}$

Hoe dit ook al sy, dié onsekerheid neem niks weg van die feit dat die ware God van die Ou Testament lank voor Moses gedien is nie. Uit die sentrale plek wat God in die Ou Testament inneem, is dit duidelik dat dit in die Ou Testament nie in die eerste plek om die mens gaan nie - ook nie om die mens se verlossing nie. Die Ou Testament is nie soteriologies nie, maar teosentries. God staan in die sentrum. Hy is die uitgangspunt en doelpunt van alles. Hý het alles geskape - só begin die heel eerste vers van die Ou Testament.42 Die Ou Testament gee egter nie ' $n$ bespreking van die leerstellings van God nie. Dit behandel ook nie die wese van God as sodanig nie, maar verkondig die uitoefening van sy heerskappy. Hierop sal ons nou nader ingaan.

\subsubsection{Die koninkryk van God}

Die uitdrukking ,die koninkryk van God" staan nie naastenby so sentraal in die Ou Testament as in die Nuwe Testament nie, hoewel nie beweer kan word, soos Engelbrecht,"3 dat die uitdrukking „,koninkryk van God" nêrens in die Ou Testament voorkom nie. Die abstrakte begrip vir koninkryk word wél enkele kere in die $\mathrm{Ou}$ Testament in verband met Jahwe gebruik, soos o.a. in Ps. $22: 29$, Ps. 103 : 19, Ps. $145: 11,13,1$ Kron. 29: 11 en Obadja 21.

Terég wys König daarop dat hierdie gegewens nie die gevolg. trekking wettig dat die betekenis van hierdie begrip slegs tot die rand van die Ou Testament behoort nie, want dat Jahwe koning is, is ' $n$ sentrale deel van die Ou-Testamentiese verkondiging. ${ }^{44} \mathrm{~J}$. Bright stel dit soos volg: "The concept of the kingdom of God involves, in a real sense, the total message of the Bible".45

R. Schnackenburg toon aan dat die gedagte van die soewereiniteit van God sy wortels diep in die Ou Testament het. ${ }^{18} \mathrm{M}$. Buber stel dit soos volg: „The realization of God's all-embracing reign is the Alpha and Omega of Israel".47

Dit gaan in die Ou Testament eintlik om die uitdrukking dat Jahwe Koning is, terwyl die abstrakte begrip ,,koninkryk" onder die invloed van die laat-Jodendom eers in die tyd van die Nuwe Testa- 
ment na vore gebring is. ${ }^{48}$ Die abstrakte begrip „koninkryk"' as 'n bepaalde, begrensde gebied waaroor Jahwe regeer, is volkome vreemd aan die Ou Testament. Voortdurend gaan dit om die aktiewe begrip „heerskappy" of „,koningskap". ${ }^{49}$ Aan dié heerskappy van Jahwe word dikwels nie duidelike inhoud gegee nie, maar wat wel duidelik is, is die feit dat die heerskappy van Jahwe nié tot Israel beperk is nie, maar alle volke insluit.

Dit is verder van die allergrootste belang dat die koninkryk van God kosmiese dimensies vertoon. Die koninkryk van God omvat nie net "geestelike aspekte" nie en is meer as ",sieleheil". Dit is duidelik dat Jahwe Koning van die hele aarde is: „Die Here is Koning; laat die aarde juig" (Ps. $97: 1$ ); ,... al die eindes van die aarde het die heil van onse God gesien" (Ps. 98:3b) is enkele voorbeelde hiervan. König wys verder daarop dat die Ou-Testamentiese shalombegrip 'n omvattende vrede of heil aandui wat heel spesifiek die aarde en die aardse insluit. In die Ou Testament kry ons ook die gedagte dat die natuur die Here loof (o.a. Ps. 19). ${ }^{\text {so }}$

Hoewel die gedagte van die koninkryk van God by Calvyn nie so eksplisiet tot uitdrukking kom nie, ${ }^{51}$ beklemtoon hy tog dat ons in die Skrif die stryd tussen God en Satan vind waarby die mens ten nouste betrokke is, en die kritiek van Calvyn op Hieronymus is juis dat hy (Hieronymus) niks van dié stryd in sy uitleg van die Heilige Skrif noem nie. ${ }^{52}$ Volgens $C$. Veenhof is die koninkryksgedagte by Calvyn ten nouste ingeweef in sy verbondsleer. In sy kommentaar op Hebr. 8 : 10 sê Calvyn dat "Nuwe Verbond" en „koninkryk van God" in die Skrif korrelate begrippe is. ${ }^{33}$

Die koninkryk van God staan sentraal in die Ou Testament en veral met die oog op die prediking, aldus $\mathbf{S}$. du Toit, is dit van groot belang dat die koninkryk van God die nadruk ontvang waarop dit reg het, en dan sal die heerskappy van God van Génesis tot Openbaring die sentrale gedagte wees. ${ }^{54}$ Wat die Nuwe Testament betref, sal verderop aangetoon word hoe sentraal die begrip „koninkryk van God" in die evangelies staan, maar dat dié uitdrukking buite die evangelies slegs enkele kere voorkom. Verder sal ons sien dat die konkrete Ou-Testamentiese begrip „Jahwe is Koning” in die Nuwe Testament vervang word (soos in die laat-Jodendom) met die meer abstrakte begrip ,die kominkryk van God", maar dat die konkrete betekenis tog in die Nuwe Testament behou word.

Samevattend kan gesê word: dát Jahwe Koning is, staan sentraal in die Ou-Testamentiese verkondiging. Sy heerskappy omvat nie slegs geestelike aspekte nie, maar vertoon duidelike kosmiese dimensies. Hy is nie net Koning van Israel nie, maar sy heerskappy is oor alle volke en oor die hele aarde.

\subsubsection{Die verbond}

W. C. van Unnik wys daarop dat die woord ,verbond" sentraal staan in die Ou Testament. Hy skryf: „Om dit werkelijk wat na te gaan zou men van bladzijde tot bladzijde het Oude Testament moeten doornemen".55 Dit is duidelik dat ,verbond" 'n kernbegrip in die Ou Testament is. „Covenant (Berith, diatheke) is such a key word 
that the Bible is itself called the Old and New Covenant". ${ }^{58}$ Koole, wat geworstel het met die „Mitte des A.T.", ${ }^{\text {s7 }}$ skryf oor die verbond in die Ou Testament soos volg: „Het O.T. is, wat ons betreft, de oorkonde van het verbond, het document met de bekendmaking en waarborg dat God en zijn volk bijeen behoren".88

Volgens $\mathrm{W}$. Eichrodt staan die verbond sentraal in die $\mathrm{Ou}$ Testament, selfs ook daar „wo das Wort berith verloren gegangen ist". ${ }^{\circ 8}$ Met verwysing na die vroeëre Israelitiese geskiedenis skryf Eichrodt: „Ferner bezeigt ihn der ganze Gang der früh-israelitischen Geschichte mit ihrer Verankerung des religiösen Solidaritätsgefühls in der Sinaitradition"”. Met verwysing na Moses skryf Eichrodt: „Und wenn in der nachmossaischen Zeit das Gottesverhältnis gilt, begründet durch ein historische Anfangstat, aufrecht erhalten unter bestimmten Bedingungen, geschützt durch einen mächtigen göttlichen Helfer, so sind damit offenbar die geistigen Grundlagen für ein Bundesverhältnis mit Gott gegeben".

Eichrodt wys ook op die ongelykheid van die partye by die totstandkoming van die verbond. ${ }^{60}$ Wanneer Von Rad oor dié ongelykheid handel, toon hy aan dat ons die verbond moet verstaan ,,als ein Verhältnis zweier ungleichen Partner. Es ist dann eine von einem Mächtigeren dem Unterlegenen aufgenötigte Abmachung. Volle Handlungsfreiheit, also auch die Freiheit zur Entscheidung, d.h. zum Schwur, hat eigentlich nur der Mächtigere; der geringere Partner verhält sich dabei rein empfangend". ${ }^{a 1}$

Hier is geén sprake van „wederkerigheid”, aldus Vriezen, „,bij het tot stand komen van een berit. Welk werkwoord ook wordt gebruikt, de berit wordt altijd eenzijdig door God tot stand gebracht, $\mathrm{Hij}$ is steeds het onderwerp van de handeling". ${ }^{62}$ Die "berit" van God en mens is dus nooit aan menslike inisiatief te danke nie. Maar, sê Vriezen tereg, die eensydige aangegane „,berit" gee aan die ander 'n reg waarop hy aanspraak kan maak; daar kom 'n element van wederkerigheid in of minstens 'n gemeenskaplikheid.

Is die verbond mono- of duopleuries en wat is die verhouding? „Men kan nooit zeggen: ò dit, òf dat, noch: beide”. ${ }^{63} \mathrm{~A}$. König het indringend op die struktuur en inhoud van die verbond ingegaan, en toon die sentrale inhoud van die verbond aan: God is onse God! Dit verkondig die Ou Testament; „Ek sal vir julle 'n God wees, en julle sal vir My 'n volk wees"..4 Dit is die kerninhoud van die genadeverbond. ${ }^{\text {s }}$ Die opvallende struktuur van hierdie verbond wor'd met die term „monopleuries" weergegee, aldus König. Hierin is die eensydige karakter van die verbond geleë, wat andersyds ook meer as een bondgenoot insluit, anders is dit geen verbond nie! Uit die verbondsluiting met Abraham blyk die eensydige karakter van hierdie verbond: „God en Abraham sit allermins om 'n konferensietafel en stel elkeen hulle voorwaardes en kom só tot 'n vergelyk, ooreenkoms of verbond". ${ }^{83}$ Alles kom van God se kant (Gen. $17: 2$ ) — dus nie: Laat ons 'n verbond sluit nie, maar: „Ek wil $m y$ verbond sluit tussen My en jou". En voordat Abraham antwoord (vs. 3), het God klaar die verbond gesluit én oor die wedersydse verantwoordelikhede (dit wil sê oor die inhoud van diè verbond) besluit: "Wat My aangaan, kyk my verbond is met jou". Vgl. vs. 7: „Ek” en 
vers 9: ,jy".

Tans moet aangetoon word dat die verhouding tussen verbond en skepping is. König skryf oor die inhoud van die verbond o.a. die volgende: „... die skepping (is) die weg (of die tegniese moontlikheid) waarlangs God wil wees wat $\mathrm{Hy}$ in ewigheid besluit het om te wees: God vir ons; dan het God in die skeppingsdaad getoon dat $\mathrm{Hy}$ in die ewigheid alreeds eens en vir altyd uit sy neutraliteit getree het om vir ons te wees alles wat Hy as Vader, Seun en Heilige Gees van ewigheid in Homself was, is en sal wees; dan is die versoening nie maar net God se reaksie op ons sonde, waardeur ons aan God en sy verbond wou ontkom en as mense sonder God, sélf "God" wou wees nie, maar dan is die versoening die deurvoering van God se oorspronklike aksie en daad waardeur $\mathrm{Hy}$ van die begin af in sy vrye liefde Homself aan ons verbind het: „Ek sal vir julle 'n God wees". ${ }^{\text {? }}$

König wys verder daarop dat juis omdat hierdie God, die God wat in vryheid liefhet, die wêreld skep, die skepping genade is. ${ }^{n *}$ En indien ons genade Bybels verstaan, as die guns van God, en nie genade as ,iets" (selfs as 'n steurende derde!) tussen God en mens sien nie, sal ons maklik begryp dat die feit dat die skepping genade is, lei tot die stelling dat die doel van die skepping die verbond is. Die verbond is naamlik die verhouding waarin God Homself teenoor sy skepping en sy skepping teenoor Hom stel. ${ }^{\circ 9}$

Barth beskryf die skepping as die „aussere Grund des Bundes" en die verbond as die ,innere Grund der Schöpfung". ${ }^{70}$ Dit beteken dat die skepping in die tyd aan die verbond voorafgegaan en as die weg en middel tot die verbond, die tegniese ruimte en die moontlikheid daarstel om die verbond te realiseer. Die verbond daarenteen, gaan weer logies en saaklik aan die skepping vooraf omdat die doel van die skepping die realisering van die verbond is. Juis omdat die verbond die genadeverbond is, is die skepping self genade, nl. 'n egte heenwysing na en 'n noodsaaklike voorbereiding tot die genade.

Wat die verhouding tussen verbond en skepping betref, sien ons dus dat daar (dogmaties) 'n ooreenkoms is: God „skep" die verbond (Gen. 17) soos Hy die aarde en mens geskape het - eensydig sý werk, maar daar is daarna tog twee bondgenote.

Uit die voorafgaande is dit duidelik dat die verbond nie iets anders as die koninkryk van God is nie, maar dieselfde saak uit 'n ander oogpunt. In die slotparagraaf kom ons op die verbond terug. Tans moet die vraag aan die orde gestel word of die Ou Testament één konsentrasie (skopus) vertoon van waaruit die hele Ou Testament verklaar kan word en of ons tog nie sal moet konkludeer dat sodanige sentrum nie bestaan nie. Uit die bespreking tot dusver is dit duidelik dat die Ou Testament baie gevarieerd is, en dat (eksegeties gesproke) daar inderdaad meer as een konsentrasie aangedui kan word.

Maar wil dit nou sê dat ons (dogmaties gesien) nie van 'n sentrum in die Ou Testament mag praat nie? Immers, die verkondiging van Jahwe staan sentraal in die Ou Testament, maar onmiddellik moet ons Fohrer gelyk gee dat "the Old Testament does not 
place God in its centre in an isolated manner, but speaks of him with regard to his action in the lives and destinies of nations and men, in creation and nature. It does not speak of God's existence and nature as it is in itself and in its complete fullness, but of God's nature and action in regard to man". ${ }^{11}$

Fohrer sien die sentrum in "the rule of God and the communion between God and man". Dit gaan hier dus oor die koninkryk van God en die verbond. Het ons in die dubbelheid met twee afsonderlike sentrums te doen wat los staan van mekaar? Het ons nie hier per slot van rekening met één en dieselfde saak slegs uit verskillende oogpunte te doen nie? Is die begrippe „koninkryk van God” en „verbond” nie keersye van dieselfde boodskap nie?

Dat Jahwe Koning is (en dus die koninkryk van God), staan sentraal in die Ou-Testamentiese verkondiging. Ons het reeds gesien dat Jahwe se heerskappy in die Ou Testament nie verstaan mag word as geldig vir net 'n bepaalde, begrensde gebied nie, maar as 'n wêreldwye heerskappy oor alle volke en die hele aarde. Die verbond staan eweneens sentraal in die Ou-Testamentiese verkondiging en verkondig aan ons dat God onse God is. In die verbond gaan dit dus slegs oor 'n ander aspek van die verhouding tussen God en sy skepping.

In die Ou-Testamentiese verkondiging gaan dit dus om Jahwe wat regeer, om sy koningskap en heerskappy oor alles en almal, maar in besonder oor sy volk.

\subsection{Die skopus van die Nuwe Testament}

\subsubsection{Inleiding}

Die vraag wat tans aan die orde kom, is: Is die horison van die Nuwe Testament nie so eng en die gerigtheid daarvan so smal dat dit nie werklik die Ou-Testamentiese teokrasie en skeppingsteologie kan dek nie? Of funksioneer die skopus (Jesus Christus) in die Nuwe Testament so breed (d.w.s. nie net soteriologies nie, maar ook kosmies) dat Jesus Christus die Here inderdaad die heerskappy van Jahwe en die verbond vergestalt?

\subsubsection{Enkele Nieu-Testamentiese uitsprake}

Johannes teken die doel van sy hele evangelie op in die woorde: „maar hierdie (tekens) is beskrywe, dat julle kan glo dat Jesus die Christus is, die Seun van God; en dat julle deur te glo die lewe kan hê in sy Naam" (Joh. $20: 31$ ). Sommige geleerdes neem aan dat ons in hierdie uitspraak met die slot van die Johannes-evangelie te doen het. ${ }^{72}$ R. H. Strachan toon egter oortuigend aan dat daar geen bewys bestaan dat die laaste hoofstuk (Joh. 21) nié van die hand van Johannes is nie. ${ }^{73}$ Tog is dit duidelik dat Johannes in hierdie vers tot 'n sekere konklusie en evaluasie van sy hele geskrif kom. ${ }^{74} \mathrm{Hy}$ beklemtoon dat sy werk slegs 'n seleksie bevat van die talryke tekens (vgl. Joh. 12:37) wat Jesus gedoen het. Teenoor die sinoptici is Johannes arm aan wonderverhale. Daar is altesaam slegs sewe tekens, terwyl hy klaarblyklik van veel meer bewus was 
(vgl. Joh. $20: 30$ „baie tekens" en Joh. $21: 25$ „baie ander dinge"). ${ }^{75}$ Hy wend egter nie ' $n$ poging aan om alles te beskryf nie. ${ }^{70} \mathrm{~F}$. L. Godet toon verder in sy kommentaar aan dat die geboortegeskiedenis, versoekings, ens. ook nié by Johannes voorkom nie. ${ }^{77}$ Calvyn wys daarop dat Johannes bekend was met die ander evangelies en daarom slegs die hoofsaak van sy leer skryf. ${ }^{78}$ Hierdie evangelie is geskryf met ' $n$ bepaalde oogmerk, ${ }^{70}$ nie om sy lesers se kennis te vermeerder nie, ${ }^{80}$ maar om hulle geloof te bevestig en te verdiep dat Jesus die Christus die Seun van God is. ${ }^{81}$ Johannes verkondig Jesus Christus dus op grond van geselekteerde feite en getuienisse. Alles in verband met Christus kom nie ter sprake nie. Wat egter wél ter sprake kom, is genoegsaam vir die ware geloof in Christus. Dit is dus ook uit hierdie uitspraak duidelik dat die Skrif 'n tendensboek is.

In Hand. $20: 27$ lees ons: „Ek het nie nagelaat om aan julle die hele raad van God te verkondig nie". Volgens R. B. Rackham is die ,hele raad" niks anders nie as die koninkryk van God, ${ }^{32}$ en T. Walker omskryf die raad as "the centre plan and purpose of God for man's salvation in all its fullness". ${ }^{83}$ Dus: alhoewel die Christene nog nie oor al die feite van die evangelie beskik het in dié sin dat hulle alles wat later in die 27 boeke van die Nuwe Testament sou staan alreeds geweet het nie, is die volle boodskap van Jesus Christus tog reeds deur die apostel aan hulle verkondig. Dit beteken dat ,die hele raad van God" nie noodwendig al die feite insluit nie, maar wel die omvattende boodskap wat sentreer rondom Jesus Christus.

Aan die hofdienaar verkondig Filippus sonder meer „die evangelie van Jesus" (Hand. $8: 35$ ). Aan die einde van die Romeinebrief noem Paulus sy evangelie „die prediking van Jesus Christus... wat... nou geopenbaar is en deur die profetiese geskrifte bekend gemaak is onder al die heidene... tot gehoorsaamheid van die geloof (Rom. $16: 25-26$ ). In Rom. $1: 5$ gee die apostel die doel van die prediking kortliks weer: „om gehoorsaamheid te verkry onder al die heidene ter wille van sy Naam".

Paulus beklemtoon herhaaldelik dat Christus sonder meer die inhoud van sy prediking is: "Hom verkondig ons" (Kol. $1: 28$ ); „Want ek het my voorgeneem om niks anders onder julle te weet nie as Jesus Christus en Hom as gekruisigde" (1 Kor. 2:2). Natuurlik het Paulus nooit iets anders verkondig nie. ,The meaning is that Paul, under the impression of his misfortune at Athens, had formed for himself anew a clear idea of his task when going to Corinth". ${ }^{84}$ Calvyn wys ook daarop dat hierdie uitspraak van die apostel nie beteken dat hy niks anders gepreek het as slegs die kruis nie, „but that, with all the abasement of the cross, he nevertheless preached Christ". ${ }^{85}$ Paulus het dus in Korinthe met die gewone praktyk van sy verkondiging voortgegaan, ${ }^{86}$ soos wat hy Jesus Christus van die begin af verkondig het. ${ }^{87}$ En ook hier in Korinthe, aldus W. E. Vine, waar die kruisevangelie as dwaasheid gereken is, het die apostel in geen opsig toegegee nie. "To anyone who readily might yield in the antagonistic forces of both Jewish and Greek prejudices the temptation would have been strong to broaden the scope of the 
Gospel, so as to avoid a direct attack against the prejudices. Not so with Paul".8s Die skopus van Paulus se verkondiging is, aldus Schlatter, „,dass Jesus der Christus ist und dass er es in Kraft seines Kreuzes ist". ${ }^{89}$ Natuurlik kon Paulus ook ander dinge van Jesus sê soos sy profetiese optrede in woord en daad, sy mag oor demone, sy oorwinning oor die dood en die graf, sy verhoging tot die Kuriosamp en sy glorieryke wederkoms, want al hierdie en derglike kom in sy geskrifte ter sprake. „Toch heeft hij in de kruisdood van Messias Jezus het hart van het evangelie gezien". ${ }^{90}$ Dit beteken egter nie dat die apostel aanhoudend sou herhaal het: „Jesus die gekruisigde, Jesus die gekruisigde" nie. Inteendeel, in sy verkondiging van Jesus Christus het hy (soos trouens ook die ander apostels) veel te sê en te verduidelik gehad. Wat kom daar nie alles in hulle geskrifte ter sprake nie! Maar in hierdie, en in talle soortgelyke uitsprake, het ons op 'n ongesistematiseerde wyse 'n beklemtoning van die doel, gerigtheid, oogmerk of skopus van die prediking van die apostels. En uit die Christologiese verklaring van die Ou Testament is dit duidelik dat hierdie konsentrasie in hul prediking op Jesus Christus nie uit die lug gegryp is nie. Natuurlik kry hulle dit nie sonder meer uit die Ou Testament nie, net soos ons ook eers vanuit die vervulling in Jesus Christus die Christologiese konsentrasie van die Ou Testament in die oog kan kry. Maar dit is wel 'n aanduiding daarvan dat elkeen wat die Ou Testament in die lig van sy vervulling verstaan het, as vanself op Jesus Christus sal konsentreer.

\subsubsection{Die koninkryk van God}

Wanneer Jesus die koninkryk van God aankondig (Matt. 12 : 28; Mark. 1 : 16, ens.), beteken dit (teen die agtergrond van die Ou Testament) dat Hy Homself bekend maak as die Koning (nl. God die Here) wat oor alle dinge heers en 'n einde aan die wanbestuur van Satan kom maak. ${ }^{91}$ Hieruit is dit duidelik dat, alhoewel die konkrete Ou-Testamentiese begrip Jahwe is Koning, in die Nuwe Testament vervang word met die meer abstrakte begrip „, die koninkryk van God", die Ou-Testamentiese konkrete betekenis tog in die Nuwe Testament behou word. Tjaart van der Walt omskryf die verhouding van Jesus Christus en die koninkryk van God soos volg: „Hulle veronderstel mekaar en gryp telkens in mekaar in. As die Menseseun gekom het, het ook die koninkryk gekom: as Hy deur die Gees van God die duiwels uitdryf - of ander beveel of magtig om dit te doen - dan het die koninkryk gekom. En as Hy weer kom as Regterkoning, dan is ook die koninkryk in al sy vervullende volheid daar". ${ }^{92}$ Ten spyte van hierdie sterk ooreenkoms tussen Jesus Christus en die koninkryk van God, is daar ook duidelike verskil. Van der Walt wys daarop dat hulle nie identiese begrippe is nie: „Die koninkryk is 'n veel omvattender begrip as die Menseseun, en terselfdertyd ook meer algemeen en on persoonlik. Die Menseseun is die persoonlik-gekonsentreerde (selfstandige) keersyde van die koninkryksbegrip, die middelpunt van die sirkel wat die koninkryk beskryf. Die koninkryk is 'n inklusiewe, die Menseseun 'n eksklusiewe begrip". ${ }^{\text {s }}$ 
Algemeen word aanvaar dat die aardse optrede van Jesus (trouens selfs die hele Nieu-Testamentiese boodskap) ${ }^{94}$ kernagtig saamgevat kan word onder die ,koninkryk van God". In die Nuwe Testament kom ook die uitdrukking ,koninkryk van die hemele" voor. Dit is kenmerkend van Matthéüs, en word as sinoniem met „,koninkryk van God” gebruik, en ,tegelyk kry ons in hierdie uitdrukking 'n samevatting van die Nuwe Testament". ${ }^{95}$ Beide was algemeen bekend in die Joodse spraakgebruik. ${ }^{90}$ Tereg het Schmidt opgemerk dat nòg Johannes die Doper, nòg Jesus hul prediking begin deur te verkondig dát daar 'n koninkryk van God is of wat die betekenis van die koninkryk is. ${ }^{97}$ Beide het bekendheid van hierdie begrip by hul hoorders veronderstel en eenvoudig verkondig: „Die koninkryk van God is naby”. (Vgl. o.a. Matt. 3 : 2 en Mark. 1 : 15). Dié algemene bekendheid van die koninkryk van God ten tyde van Jesus bewys hoe sentraal die boodskap agter die uitdrukking ,koninkryk van God" in die verkondiging van die Ou Testament gestaan het. J. Bright stel dit soos volg: „So paramount was the notion of the kingdom of God in the mind of Jesus that one scarcely grasp His meaning at all without some understanding of it".98 Niemand het ooit Jesus na 'n nadere verduideliking gevra nie, en nooit het $\mathrm{Hy}$ die koninkryk gedefinieer nie. Inderdaad, "the kingdom of God lay within the vocabulary of every Jew".

As die uitdrukking ,koninkryk van God", wat 'n oorheersende plek in die sinoptiese evangelies inneem, in die res van die Nuwe Testament terugtree teenoor uitdrukkings soos geregtigheid, vrede, blydskap, verlossing, lewe ens., is daar geen sprake van teenstelling in die verkondiging van die Nuwe Testament nie, maar veel eerder sal van sinonieme gepraat moet word. ${ }^{\circ 0}$ Verder kan ook aangeneem word dat die probleem wat 50-60 jaar gelede in die sentrum van teologiese diskussie gestaan het, $n$ l. of die koms van die koninkryk in gerealiseerde of in konsekwent-futuristiese sin verstaan moet word, min of meer opgelos is in die erkenning dat albei waar is. ${ }^{100}$

In die Nuwe Testament is daar, afgesien van die onderskeid, egter ook 'n sekere gelykstelling tussen Jesus (die Koning) en die koninkryk van God. Dit beteken nie alleen dat die abstrakte begrip „,koninkryk van God" in die Nuwe Testament tog konkrete betekenis het nie, maar ook dat Jesus die Here van die Ou Testament is, wat Koning oor die hele aarde is. Matt. $12: 27 \mathrm{v}$. is hier van besondere betekenis. In hierdie uitspraak, aldus König, stel Jesus die feit dat die koninkryk van God gekom het in 'n beslissende verband met die feit dat Hy duiwels uitdryf. „Die opvallende feit is nou egter dat dit nie net $\mathrm{Hy}$ is wat duiwels uitdryf nie. Hy verwys self na die „,seuns" of leerlinge van die Fariseërs wat ook duiwels uitdryf. Dit is dus nie die feit dát duiwels uitgedryf word wat dien as aanduiding dat die koninkryk gekom het nie, maar wel die feit dat $\mathrm{Hy}$ die duiwels uitdryf - wat eintlik op dieselfde neerkom as dat Hy dit deur die ,,vinger" of die krag van God doen — en nie soos die talryke eksorsite deur allerlei magiese formules nie".101

Uit hierdie voorbeeld, wat maklik vermenigvuldig kan word, blyk hoe identies die Persoon van Christus en die koninkryk van God is. Hieruit blyk ook hoe sentraal Jesus in die evangelie staan. 
Hy verkondig nie ,iets" nie, maar Iemand - Homself! Jesus is die Koning in wie se Persoon en werk die laaste groot beslissing vir die wêreld val. In Hom „laat God sy koninkryk in die wêreld kom", dit wil sê, maak God finaal sy heerskappy oor die wêreld bekend. Dit beteken dat die skopus van die Nuwe Testament saamval met die van die Ou Testament. Jesus Christus is meer as die Messias wat sou kom. In Hom kry die heerskappy van Jahwe oor alle dinge gestalte. Dit is dus nie vreemd dat Jesus Christus ook kosmiese betekenis volgens die Nuwe Testament het nie.

\subsubsection{Die kosmiese betekenis van Jesus Christus}

Tereg wys Cullman daarop dat die horison van die Nuwe Testament nie kleiner is as dié van die Ou Testament nie. Wanneer hy dié vraagstuk bespreek, stel hy dit soos volg: „Diese Verengung des Horizonts im Neuen Testament ist jedoch nur scheinbar"..102 Hy toon aan dat dit lyk asof daar net 'n konsentrasie is op die verlossingswerk van Jesus Christus, maar dat die Ou-Testamentiese uitgangspunt nl. die skepping, ook in die skopus van die Nuwe Testament ingesluit is. Van groot betekenis vir die formulering van die skopus van die Nuwe Testament is die volgende uitspraak van Cullman: ,So ist die Schöpfung nicht nur auch im Blickfeld des Neuen Testaments, sondern sie ist es in erhöhten Masse. Christus is der kosmische Erlöser". ${ }^{103}$

Die Nuwe Testament het dus wel 'n Christosentriese konsentrasie, maar dit is nie beperk tot die Messiaanse of soteriologiese nie, aangesien Jesus Christus ók kosmiese betekenis het in die Nuwe Testament. In Jesus se aardse optrede kom hierdie aspek al sterk na vore. Hy kom nie net „siele" red nie, Hy kom mense red. Meer nog: Hy kom die aarde nuut maak! Daarom vergewe $\mathrm{Hy}$ nie net sonde nie, maar genees ook siektes. ${ }^{104} \mathrm{Hy}$ genees nie net siekes nie, maar onderwerp ook die natuur aan sy heerskappy. Enkele voorbeelde sal hierdie stelling nader toelig. Wat die genesing van siekes betref, verwys ons na die genesing van die maansieke kind (Matt. $17: 14-$ 21; Mark. 9 : 14-29; Luk. 9 : 37-34a). Uit hierdie genesingswonder blyk dat die duiwels voor Hom wegvlug, en volgens Matt. 12 . $27-28$ neem die duiweluitdrywing 'n besondere belangrike plek in die optrede van Jesus in. Jesus doen dit om daardeur aan te toon dat Hý die HERE is wat as Koning regeer en dat die koninkryk van God in Hom gekom het. Hierdie kosmiese aspek van sy heerskappy is van die allergrootste belang by die formulering van die skopus van die Nuwe Testament.

Jesus se heerskappy strek hom ook uit oor die natuur: Hy maak die storm stil (Mark. $4: 35-41$ ), vervloek die vyeboom (Mark. 11 : $12-14,20-26$; Matt. $21: 18-22)$, en vermeerder tweekeer brode en visse (Mark. $6: 30-44$ en $8: 1-9$ ) ens.

Samevattend kan dus gesê word dat Jesus se aardse optrede, en in besonder sy wonderwerke, bewys daarvan is dat $\mathrm{Hy}$ nie net ",sieleheil" gebring het nie, maar dat sy" koms en werk direk betrokke is op die hele mens, én op die aarde in kosmiese sin. 
4.2.5. Jesus Christus is die vervuller en inhoud van die verbond

In Jesus Christus leer ons die een ware God ken, en dárom is God van die begin af God vir ons, dit wil sê, ons Koning én Koning van die heelal; ons is sy volk: dit wil sê, sy onderdane, terwyl die heelal sy ryksgebied is. Anders gestel: „koninkryk van God" is die keersy van die ,verbond van God". 105

Dit is 'n daad van God se eindelose goedheid dat Hy nie neutraal teenoor ons staan nie, maar Hom in Christus aan ons verbind om God vir ons te wees. Dié goedheid van God het ons nie verdien nie - nie kragtens ons skepselwees nie en veel minder kragtens ons gevallenheid. Ons het God se genade verbeur en verdien dat God die breuk vanweë die sonde aanvaar en die gemeenskap beëindig. Maar in sy mensliewendheid (Tit. $3: 4$ ) kom Hy in Jesus Christus omdat Hy dié breuk nie aanvaar nie, maar sy verbond deurvoer, handhaaf en herstel.

Dié verbond verplig die mens tot dankbaarheid en gehoorsaamheid. In Christus het God alles gedoen, deur Josus is die wêreld met God versoen en reken God hulle hul misdade nie toe nie $(2 \mathrm{Kor}$. $5: 18,19)$. Dit is die eis van die verbond: „en julle sal vir My 'n volk wees".

In sy persoon realiseer Jesus Christus die verbond (wat Israel moes doen deur die getroue bondgenote van God te wees, maar waarin hulle juis misluk het) omdat $\mathrm{Hy}$ die verbond is. Hy is immers vere deus et vere homo. As vere deus is Hy Immanuel: God met ons, onse God - en dit is juis "God se deel" van die verbond. As vere homo is $\mathrm{Hy}$ die regverdige mens as representant van die nuwe mensheid, nl. dit wat die mense se deel in die verbond was. So is Israel se geskiedenis vervul in Jesus Christus.

\subsubsection{Die vervulling van die Ou-Testamentiese beloftes in Jesus Christus}

Tans moet die beslissende aspek van die nuwe-Testamentiese verkondiging na vore gebring word, nl. die vervulling van die beloftes vall die Ou Testament in Jesus Christus.

Volgens die Nuwe Testament is die hele Ou Testament in Jesus Christus vervul, ${ }^{106}$ en hoe omvattend die vervulling van die hele Ou Testament in Jesus Christus is, blyk bv. uit die feit dat elkeen van die groot historiese dade van God hul toespitsing in Jesus Christus het: die skepping in Jesus Christus (2 Kor. 4:3-6); die Abrahamgeskiedenis se diepste betekenis is eweneens die kindskap van Jesus Christus en die vryheid deur Jesus Christus (Gal. $4: 20-$ 31 , veral vs. $31 ; 5: 1$ en $3: 29$ ). Ook die uittog uit Egipte en die paaslam se ware betekenis is Jesus Christus ( 1 Kor. $5: 7-8$ ). Uit hierdie enkele voorbeelde sien ons dat nie net die beloftes (die toekoms) van die Ou Testament nie, maar ook die geskiedenis (verlede) van die $\mathrm{Ou}$ Testament se ware betekenis geleë is in Jesus Christus.

Die Christologiese interpretasie van die ou Testament in die Nuwe Testament vind op 'n spesifieke wyse plaas, $n l$. in die sin van die vervulling van die Ou Testament in Jesus Christus. Hoewel die Ou Testament duidelik beloftekarakter dra, kan ons nie die $\mathrm{Ou}$ 
Testament eensydig as boek van die belofte teenoor die Nuwe Testament as boek van die vervulling stel nie. Immers, die blote feit dat die hele Ou Testament ná Christus nóg in die kerk erken word en funksioneer, dui op die radikale verskil tussen die vervulling van Bybelse beloftes en voorspellings wat uitkom. ${ }^{107}$

Nogtans is die begrip ,vervulling” een van die belangrikste begrippe in verband met Jesus Christus (vgl. bv. Matt. $1: 22 ; 2: 15$; $2: 17 ; 4: 14 ; 8: 17 ; 12: 17 ; 13: 14 ; 13: 35 ; 21: 4$ en $27: 9$ ). En naas hierdie vaste formule is daar talle sitate uit die Ou Testament waarvan ons sommige kortliks aangedui het. ${ }^{108}$ Die konsentrasie van hierdie aanhalings op Jesus Christus is kenmerkend van die inklusiewe vervulling van die hele $\mathrm{Ou}$ Testament in die koms van Jesus Christus. König het breedvoerig aangetoon dat 'n bepaalde eenheid die groot verskeidenheid Ou-Testamentiese beloftes ten grondslag lê, en dat hierdie eenheid konkreet word wanneer Jesus Christus verskyn. Hy wys bv. daarop dat sekere verwagtings in die Ou Testament ontwikkel en deurloop tot die einde (bv. die Dag van die Here, die Koningskap van Jahwe en die Dawidiese koningskap) én dat ál hierdie verwagtings saamgetrek en vervul word in Jesus Christus. „Hierdie eenheid in Israel se toekomsvisie word in die Nuwe Testament veronderstel in uitsprake soos Hand. $13: 27$ en 32 waar merkwaardig inklusief gepraat word van „die woorde van dic profete" wat vervul is deurdat Christus veroordeel is, en ook van "die belofte" wat aan die vaders gedoen is (wat sekerlik op 'n hele reeks verskillende Ou-Testamentiese beloftes betrekking het) wat God vervul het deur Jesus op te wek". ${ }^{100}$ Ook Berkouwer verklaar: „In Christus wordt de vervulling gezien van het ganze O.T... Het gaat om een totaal getuigenis, dat centraal en in samenhang heenwijst naar de komende Verlosser Jesus Christus". ${ }^{110}$

Die hele Ou Testament word in Jesus Christus vervul en die hele $\mathrm{Ou}$ Testament getuig van Jesus Christus (Joh. 5 : 39). Die Messiasfiguur is ' $n$,randfiguur" in die Ou Testament en die Nuwe Testament verkondig Jesus Christus as Jahwe wat regeer. Terselfdertyd sien ons dat die skrywers van die Nuwe Testament die Ou Testament Christologies siteer en interpreteer. Beteken dit nou 'n verengde Messiaanse interpretasie? Nee. Allereers moet daarop gewys word dat die konsekwente Christologiese interpretasie van die Ou Testament nié 'n nuwe element is wat by die skopus van die Ou Testament gevoeg word nie. In Rom. $16: 25-26$ sê Paulus immers dat hy die evangelie van Jesus Christus deur die Ou Testament aan die heidene verkondig. ${ }^{11}$ Verder is die Christologiese konsentrasie ook geen verenging nie, want in Jesus Christus kry die heerskappy van Jahwe gestalte. Jesus is dus méér as Messias, daarom is die Nuwe Testament in sy verkondiging van Jesus Christus ook nie net soteriologies gekonsentreer nie, maar word die skopus (Jesus Christus) so breed verkondig (koninkryk van God, verbond) dat die skopus van die Ou Testament inderdaad hierdeur gedek word.

Die skopus van die Heilige Skrif (Jahwe of Jesus Christus die Here, koninkryk van God, verbond) verbind Ou en Nuwe Testament met mekaar. ${ }^{112}$ L. Floor stel dit soos volg: „Het komt ons voor dat de wezenlijke eenheid tussen het Oude en het Nieuwe Testament 
gezocht moet worden in het uitzien naar de komst van het koninkrijk van God".'113

\section{Slot}

Uit die voorafgaande Bybelse ondersoek het dit duidelik geword dat die hele Skrif 'n bepaalde gerigtheid het, 'n skopus wat met verskillende begrippe aangedui kan word: die koninkryk van God, die verbond, Jesus Christus. Alles kom daarop aan dat die hele Skrifnavorsing en die leer oor die Heilige Skrif op hierdie skopus gerig sal word, juis omdat dit in die Heilige Skrif onmiddellik gaan om sy boodskap of skopus.

Die probleem ontstaan egter by die dogmatiese vulling van die begrip ,skopus”. Wat is die omvang van hierdie begrip? Implisiet hierin is geleë die vraag na die gevaar van dualisme. Sedert die vroegste tye is die heil in Jesus Christus as die skopus en doel van die Heilige Skrif aangedui. ${ }^{114}$ Natuurlik het nie een van die teolö̈ (hierbo genoem) die teokrasie en sosiale idenal (Van Ruler) eksplisiet uitgesluit nie. Indien dit die geval sou wees, scu ons tot geen ander gevolgtrekking kon kom as dat hulle in 'n onskriftuurlike dualisme verval het nie. Die vraag bly egter: moet dic teokrasie en sosiale ideaal nie ook eksplisiet ingesluit word in die skopus van die Heilige Skrif nie? Dié vraag lei tot 'n ander vraag: gaan dit in die Skrif om die onmiddellike doel of die oorspronklike doel van God met sy Woord? Anders gestel: verkondig die Skrif slegs die verlossing en heil van die sondaar of ook die skepping en herskepping van alle dinge? Is die Heilige Skrif slegs 'n bekeringsboek of ook die Boek van skepping en toekoms?

Heyns het indringend op die skopus van die Skrif ingegaan en formuleer die skopus soos volg: „Die sentrum van die Skrif is Gods koninkryk, en die sentrum van dié sentrum is Jesus Christus". ${ }^{115}$ Hy gee dus aan die sentrale boodskap van die Skrif 'n dubbele dimensie en motiveer dit soos volg: „As die Bybel 'n boek was wat nét oor die sondige wêreld gehandel het, dan was Jesus sonder meer die sentrale boodskap. Maar nou handel die Bybel oor 'n wêreld en oor mense wat aan die begin nie sondig was nie, en aan die einde nie meer sondig sal wees nie. Eers met die verskyning van die sonde, waarvan ons op die eerste bladsye van die Bybel lees, het Jesus die Weg tot verlossing geword, daarom is $\mathrm{Hy}$ nie die einddoel nie, maar Gods weg met die sondige wêreld op pad na die einddoel".110

Dit is egter ' $n$ vraag of Heyns met hierdie ,,skopus in die skopus" reg laat geskied aan Jesus Christus. Hy beperk die betekenis van Jesus uitdruklik tot die soteriologie (,As die Bybel 'n boek was wat nét oor die sondige wêreld gehandel het, dan was Jesus sonder meer die sentrale boodskap"), terwyl die kosmiese dimensie waarin Jesus Christus in die Nuwe Testament verkondig word nie tot hul reg kom nie (o.a. Kol. 1 : 15-17; Ef. 1 : 10 naas die feit waarop reeds gewys is, $\mathrm{nl}$. die heerskappy van Jahwe - die koninkryk van God - in Jesus Christus gestalte kry). As hierdie kosmiese betekenis van Jesus tot sy reg kom, kan Hy as die einddoel van God gesien word. 
Op die vraag of die skopus van die Skrif die „onmiddellike” of heilsdoel, of die „oorspronklike”, d.w.s. skeppingsdoel is, sou mens dus moet antwoord dat daar wel slegs een weg is waarlangs die skeppingsdoel bereik kan word en dit is langs die weg van die heilsdoel, maar dat dit uiteindelik om die skeppingsdoel gaan.

H. Denkema.

1 Die Betroubare Woord - 'n Ondersoek na die aard van die Skrifgesag. Desember 1973.

2 Vgl. o a. H. W. Rossouw: Klaarheid en Interpretasie, Amsterdam 1963; J. N. D. Kelly: Early Christian Creeds, Londen 1960, p. 13; E. FlessemanVan Leer: Het Oude Testament bij de apostolische vaders en de apologete, in: Nederlands Theologische Tijdschrift, 9e jrg,, 1954-55.

3 Vgl. G. C. Berkouwer: Nabetrachting op het Concilie, Kampen 1968, p. 134.

4 W.A. 2, pp. 302, 361 .

5 W.A. 7, p. 385 .

6 W. J. Kooiman: Luther en de Bijbel, Baarn 1961, p. 174.

7 CR 6, p. 459 v.

8 Institutes of Christian Religion IV, 1, 12.

9 H. Bavinck: G.D. I, p. 470.

10 H. Bavinck: a.w., p. 471.

11 O.a. in: De Heilige Schrift II, pp. 79 v., 86 v., 98 v., 106 v., hfst. VI.

12 K.D. I, 2, pp. 511-516; 536; 538; 569; 598; 807 v.

13 Grunlagen der Dogmatik I, p. 333 v.; II, p. 735.

14 A.w. I, p. 334.

15 Die oorspronklike teks van Dei Verbum is gepubliseer in Sacro-sanctum Oecumenium Concilium Vaticanum II. Constitutiones, Decreta, Declarariones, Rome 1966.

16 Dei Verbum, arts. 11 en 12. Art. 11 geskied met 'n beroep op $0 . a$. Augustinus, Thomas, Trente en Pius XII.

17 Voortdurend wys Van Ruler op die onmisbaarheid van die O.T. vir die Christelike denke en die kerklike prediking, maar hiervan kan nie afgelei word dat hy die N.T. devalueer nie - vgl. die kritiek van L. Floor: De Nieuwe Exodus, Potchefstroom 1969 (diss.), p. 6.

18 Vir Van Ruler se gedagtes oor „Teokrasie", sien my diss. p. 265 v.v.

19 A. A. van Ruler: Schriftgezag en Kerk, in: De Bijbel in het geding, Nijkerk 1968, p. 126.

20 G. C. Berkouwer: Verontrusting en Verantwoordelikhieid, pp. 121 v; De Heilige Schrift II, pp. 96 v., 107, 109.

21 Berkouwer: a.w. II, p. 106.

22 H. L. Ellison: The Message of the Old Testament, Paternoster 1969, p. 11.

23 P. A. H. de Boer: De Boodschap van het Oude Testament, Leiden 1940, p. 10.

24 A. S. van der Woude: Verwachting en Vervulling, Amsterdam 1969, p. 10.

25 G. Fohrer: The Centre of a Theology of the Old Testament, in: Nederduits Geref. Teologiese Tydskrif, September 1966, p. 198.

26 G. F. Hasel: Old Testament Theology, Grand Rapids 1972, p. 49.

27 J. L. Koole: Overwezingen bij een Theologie van het Oude Testament, in: Gereformeerd Theologische Tijdschrift, Februarie 1973.

28 Idem, p. 6. 
29 G. Fohrer: a.a., in: Ned. Geref. Teologiese Tydskrif, p. 199.

30 Vgl. G. F. Hasel: a.w., p. 56, voetnoot 43.

31 G. F. Hasel: a.w., p. 50.

32 G F. Hasel: a.w., p. 51.

33 Idem.

34 J. L. Koole: a.a., in: Gereformeerd Theologisch Tijdschrift, p. 6

35 G. Fohrer: a.a., p. 199.

36 G. F. Hasel: a.w., p. 54, voetnoot 33. Vgl. R. Smend: D:e Mitte des Alten Testaments, in: Theologische Studien, Heft 101, EVZ-Verlag, Zürich 1970.

37 G. F. Hasel: a.w., p. 51 v., gee 'n oorsig van die uiteenlopende standpunte.

38 Th. C. Vriezen: Hoofdlijnen der Theologie van het Oude Testament, Wageningen 1954, p. 206.

39 J. de Groot en A. R. Hulst: Macht en Wil, Nijkerk s.j., p. 125.

40 A.w., pp. $128-129$.

41 G. von Rad: Theologie des Alten Testaments I, München 1961, p. 179.

42 Vgl. ook Ps. 148.

43 B. Engelbrecht: Agtergronde en Grondlyne van die Teokratiese Visioen, p. 1.

44 A. König: Jesus Christus die Eschatos, Pretoria 1970, 322.

45 J. Bright: The Kingdom of God in Bible and Church, Londen 1955, p. 7

46 R. Schnackenburg: God's Rule and Kingdom (oorspronklike titel: Gottes Herrschaft und Reich, Freiburg 1963), p. 11.

47 M. Buber: Königtum Gottes, LXIV (aangehaal by R. Schnackenburg: a.w., p. 11 .

48 A. König: a.w., p. 322.

49 Idem.

50 A. König: a.w., p. 329.

51 L. Floor: Calvyn se hermeneutiek in sy betekenis vir ons tyd, in: In die Skriflig, Mei 1970, p. 9.

52 D. Schellong: Calvins Auslegung der Synoptischen Evangelien, München 1969 , p. 18.

53 C. Veenhof: Het Woord Gods in den brief aan de Hebreën, Amsterdam 1946 , p. 59.

54 S. du Toit: Die Koninkryk van God in die Ou Testament, in Die Koninkryk van God, Potchefstroom 1969, p. 12.

55 W. C. van Unnik: „Verbond”, (Kernwoorden in het Christelijk geloof), in: Rondom het Woord, Oktober 1969, p. 390.

56 H. Berkhof en P. Potter: Key Words of the Gospel, SCM, New York. s.j., p. 25.

57 J. L. Koole: a.a., in: Gereformeerd Theologisch Tijdschrift, Feb. 1973, p. 6.

58 Idem., p. 11.

59 W. Eichrodt: Theologie des Alten Testaments I, Berlyn 1950, p. 6.

60 A.w., p. 7.

61 G. von Rad: a.w., p. 135.

62 Th. C. Vriezen: Moet de oudtestamentische exegese en Theologie afzien van het woord "verbond"?, in: Rondom het Woord, 14e jrg. no. 3 . Julie 1972, p. 279.

63 Th. C. Vriezen: a.w., p. 281.

64 Hierdie teks kom verreweg die meeste voor in die O.T.!

65 A. König: a.w., p. 228.

66 A. König: a.w., p. 229. 
67 A. König: a.w., p. 230.

68 A. König: a.w., p. 218.

69 A. Kön:g: a.w., p. 219.

70 K. Barth: K. D. III, 1, p. 262 (vgl. K.D. II, 1, p. 576).

71 G. Fohrer: a.a., in: Ned. Geref Teologiese Tydskrif, Sept. 1966, p. 199 (onderstreping deur my - H.D.).

72 W. F. Albright/D. N. Freedman: The Gospel according to John, in: The Anchor Bible, New York 1970, p. 1057.

73 R. H. Strachan: The Fourth Gospel, Londen 1941, p. 333.

74 A. M. Hunter: The Cambridge Bible Commentary, Cambridge 1965, p. $19 \mathrm{l}$.

75 A. Wikenhauser e.a: Het Evangelie volgens Johannes (oorspr. Regensburger Neues Testament), Antwerpen 1964, p. 452.

$76 \mathrm{Vgl}$. W. Temp'e: Readings in St. John's Gospel, Londen 1959, p. 392; A. Schlatter: Der Evangelist Johannes, Stuttgart 1960, p. 363; R. Bultmann: Das Evangelium des Johannes, Göttingen 1959, p. 541.

77 F. L. Godet: Commentary on the Gospel of John, Grand Rapids 1893. p. 453.

78 J. Calvyn: Het Evangelie van Johannes, Goudriaan 1971, p. 850.

79 J H. Barnard: Gospel according to John (I.C.C.), Edinburgh 1963, p. 685.

80 A. Wikenhauser e.a.: a.w., p. 428.

81 B. F. Westcott: The Gospel acconding to St. John, Londen 1953, p. 198. Vgl. ook S. Schulz: Das Evangelium nach Johannes, Göttingen 1972, p. 248.

82 R. B. Rackham: The Acts of the Apostels, Grand Rapids 1964, p. 391. Vgl. F. F. Bruce: Commentary on the Book of Acts, Edinburgh 1962, p. 415; A. Schlatter: Die Apostelgesichte, Stuttgart 1962, p. 249.

83 T. Walker: The Acts of the Apostles, Chicago 1965, p. 447.

84 F. W. Grosheide: Commentary on the First Epistle to the Corinthians, Londen 1953, p. 59.

85 J. Calvyn: Commentary on the Epistles of Paul the Apostle to the Corinth:ans, Grand Rapids 1948, p. 97.

86 F. F. Bruce: I and II Corinthians, Londen 1971, p. 37.

87 T. R. Applebury: Studies in first Corinthians, Joplin, Missouri 1963, p. 33.

88 W. E. Vine: I Corinthians, Grand Rapids 1961, p. 34.

89 A. Schlatter: Die Korintherbriefe, Stuttgart 1962, p. 25.

90 F. J. Pop: De Eerste Brief van Paulus aan de Corinthiërs, Nijkerk 1965 , p. 53.

91 A. König: a.w., p. 325.

92 Tjaart van der Walt: Die Koninkryk van God - naby!, Kampen 1962, p. 84 .

93 Tjaart van der Walt: a.w., p. 85.

94 Vgl. K. L. Schmidt: TWzNT I, p. 582 (ook p. 584).

95 W. J. Snyman en L. Floor: Die Koninkryk van God in die Nuwe Testament, in: Die Koninkryk van God, Potchefstroom 1969, p. 34.

96 C. H. Dodd: The Parab'es of the Kingdom, Cambridge 1936, p. 34.

97 K. L. Schmidt: TWzNT I, p. 585.

98 J. Bright: The Kingdom of God in Bible and Church, Londen 1955, p. 17.

99 B. Engelbrecht: a.w., p. 2.

$100 \mathrm{Vgl}$. H. N. Ridderbos: De Komst van het Koninkrijk, Kampen 1950, p. 6 vv.

101 A. König: a.w., p. 327.

102 O. Cullmann: Die Schöpfung im Neuen Testament, in: Ex Auditu Verbi, Kampen 1965, p. 56 . 
103 o. Cullmann: a.a., p. 58.

104 A. König: a.w., p. 329.

105 A. König: a.w., p. 322.

106 Vgl. Luk. $24: 27$ en Joh. $1: 46$.

107 Vgl. G. C. Berkouwer: De Persoon van Christus, Kampen 1952, hfst. VIII.

108 Vgl. hfst. 3, par. 3.5. van my proeiskrif.

109 A. König: a.w., p. 161.

110 G. C. Berkouwer: a.w., p. 91.

111 Vgl. H. N. Ridderbos: Commentaar op het Nieuwe Testament: Aan de Romeinen, Kampen 1959, p. 354.

112 Vgl. K. S. van Wyk de Vries: 'n Oriëntering in breë trekke: Begripsen plekbepaling van die Koninkryk van God t.o.v. en in verhouding tot die uitverkiesing, die kerk, die verbond en die maatskappy, in: In die Skriflig, Aug.-Sept. 1970, p. 10.

113 L. Floor: a.w., p. 10. Vgl. H. N. Ridderbos: When the t:me had fully come, Grand Rapids 1957, p. 9; H. N. Ridderbos: De Komst van het Koninkrijk, Kampen 1950, pp. 24, 28.

114 Vgl. o a. die standpunte van Irenaeus, Augustinus, Luther, Bavinck, Barth en Berkouwer.

115 J. A. Heyns: Brug tussen God en Mens, Pretoria 1973, p. 91.

116 J. A. Heyns: a.w., p. 92-93. 